\title{
Türkiye'nin 7 akarsu havzasında horozbina, Salaria fluviatilis (Asso,1801), balığına ait boy-ağırlık ilişkisi
}

\section{The length-weight relationship of freshwater blenny, Salaria fluviatilis (Asso, 1801) in 7 drainage basin of Turkey}

\author{
Ali İhan* • M. Ruşen Ustaoğlu • Sait Berberoğlu
}

Ege Üniversitesi Su Ürünleri Fakültesi, Su ürünleri Temel Bilimler Bölümü İ̧sular Biyolojisi Anabilim Dalı, 35100, Bornova, izmir, Türkiye ${ }^{*}$ Corresponding author: ali.ilhan@ege.edu.tr

\begin{abstract}
The present work aimed at determining the length-weight relationship of freshwater blenny (Salaria fluviatilis) in the 7 drainage basins of Turkey. For this purpose, total of 652 freshwater blenny specimens were examined belonging to the Marmara, Küçük Menderes, Western Black Sea, Antalya, Eastern Mediterranean, Seyhan and Ceyhan basins. Total lengths ranged from 2.0 to $12.9 \mathrm{~cm}$ and total weights ranged from 0.10 to $33.82 \mathrm{~g}$. Length-weight relationship parameters were computed as $a=0.0135, b=3.004, r^{2}=0986$ for all individuals of the species in the freshwater of Turkey. In addition, growth type were determined isometric in 5 basin, positive allometric in 1 basin and negative allometric in 1 basin.
\end{abstract}

Keywords: Salaria fluviatilis, freshwater blenny, length-weigh relationship, freshwater of Turkey

Özet: Bu çalışmada Türkiye'nin 7 akarsu havzasından toplanmış olan Horozbina Balığı (Salaria fluviatilis)'na ait boy-ağırlık ilişkisinin ortaya çıkarıması amaçlanmıştır. Marmara, Küçük Menderes, Batı Karadeniz, Antalya, Doğu Akdeniz, Seyhan ve Ceyhan havzalarına ait akarsulardan toplanmış olan 652 birey incelenmiş̧tir. Tüm bireyler dikkate alındığında türün Türkiye içsularındaki total boy dağılımı $2.0-12.9 \mathrm{~cm}$, total ağırlık dağılımı 0.10-33.82 g, boy-ağırlık ilişkisi parametreleri $a=0.0135, b=3.004, r^{2}=0.986$ olarak hesaplanmıştır. Ayrıca, büyüme tipi havzaların 5'inde izometrik, 1 havzada pozitif allometrik ve 1 havzada da negatif allometrik olarak belirlenmiş̧ir.

Anahtar kelimeler: Salaria fluviatilis, Horozbina Balı̆̆ı, Boy-Ağırlık lilşkisi, Türkiye içsuları

\section{GíRiş}

Kaynaklarda total boy uzunluğunun en fazla $15 \mathrm{~cm}$ olduğu bildirilen (Krupp ve Schneider, 1989) S. fluviatilis, tatlısulara adapte olmuş bir tür olup, genellikle sahile yakın göllerde ve az derin akarsularda bulunur. Özellikle temiz akarsuların taşlık ve kayalık zonlarını tercih eden tipik bir zemin balığıdır. Beslenme yönünden karnivor olup başlıca gıdasını çeşitli su böcekleri, Krustaseler ve küçük balıklar oluşturur. Üreme periyodu Nisan-Haziran arasıdır. Genellikle bütün Güney Avrupa ve Kuzeybatı Afrika sahillerinde yayılış gösteren bu tür, ülkemizin sadece Ege ve Akdeniz sahilleri, Asi nehri ve kolları ile İznik gölünden rapor edilmiştir. İnsan gıdası yönünden hiçbir ekonomik önemi olmamakla beraber, başka balıklara yem hazırlamada hayvansal protein kaynağı olarak kullanılırlar. Ayrıca, süslü renklerinden dolayı akvaryumlarda beslenebilirler (Geldiay ve Balık, 2007).

Boy-ağırlık ilişkisi, balık biyolojisi açısından son derece önemlidir. Boy-ağırlık ilişkisi parametreleri (a ve b), balığın boyundan ağırlığının tahmin edilmesine, kondisyon indeksinin hesaplanmasına, farklı habitatlardaki populasyonların morfolojilerinin ve yaşam süreçlerinin karşılaştırılmasına imkan verir. Ayrıca boy-ağırlık ilişkileri ile balık büyümesinin izometrik veya allometrik olup olmadığı ifade edilir.

\section{MATERYAL VE YÖNTEM}

Çalışma konusu örnekler Ege Üniversitesi Su Ürünleri Fakültesi Müzesi İçsu Balıkları Kolleksiyonundan temin edilmiştir (ESFM/PISI). Çalışmada, müzede yer alan 7 farklı havzanın akarsularından toplanmış olan balık örnekleri incelenmiştir. Eşey ayrımı gözetilmeden incelenen örneklerin boy ölçümleri $1 \mathrm{~mm}$ hassasiyetli ölçüm cetveli, ağırlık ölçümleri ise $0.01 \mathrm{~g}$ hassasiyetli dijital terazi ile yapılmıştır. Boy ağırlık ilişkisinin incelenmesinde $W=a L^{b}$ denkleminden yararlanılmıştır (Ricker, 1975). Burada 'W' gram cinsinden balığın total ağırlığını, 'L' $\mathrm{cm}$ cinsinden balığın total uzunluğunu, "a" ve "b" katsayıları ise büyüme parametrelerini ifade etmektedir. Türün büyüme tipini belirlemek amacıyla; $t_{s}=b-3 / s e(b)$ eşitliğinden yararlanılmıştır (Sokal ve Rohlf 1987). Burada ts; t-test değeri, b; eğim değeri ve se(b); ise (b) eğim değerinin standart hatasıdır. Büyümenin izometrik ya da allometrik olduğuna karar vermek için, hesaplanan t-test değeri tablodaki kritik değerle karşılaştırılmıştır.

\section{BULGULAR}

Türkiye'nin 7 akarsu havzasından örneklenmiş olan toplam 652 Horozbina balığının incelenmesi sonucunda total boy dağılımının 2.0-12.9 cm, total ağırlık dağılımının ise 0.1- 
$33.82 \mathrm{~g}$ arasında değiştiği görülmektedir. İlgili türün incelenen periyottaki kondisyonunu da ifade eden "a" değeri tüm bireyler için 0.0135 olarak hesaplanmıştır. Ayrıca, eğim "b" değeri Marmara, Küçük Menderes ve Batı Akdeniz havzalarında 3'ün üzerinde bir değere sahipken, Antalya, Doğu Akdeniz, Seyhan ve Ceyhan havzalarında ise söz konusu değer 3'ten daha küçüktür. Havza ayrımı yapılmaksızın tüm bireyler dikkate alındığında $S$. fluviatilis türünün büyüme modelinin izometrik tipte olduğu görülmüştür (t-test=0.275, $t<t_{0.05}, \mathrm{n}>200=1.65$ ). Havzalar dikkate alınarak yapılan ayrımda ise 5 havzada izometrik tipte büyüme modeli gözlenirken, 1 havza örnekleri pozitif allometrik, 1 havzada da negatif allometrik büyüme modeli tespit edilmiştir (Tablo 1).

\section{TARTIŞMA VE SONUÇ}

Kaynaklarda total boylarının 15 cm'ye erişebildiği belirtilen (Krupp ve Schneider, 1989) S.fluviatilis üzerine yapılmış çalışmalar incelendiğinde söz konusu değere en yakın boy değeri $12.9 \mathrm{~cm}$ ile bu çalışmada elde edilmiştir. Önceki yıllarda ülkemizde İznik Gölü'nde, Avrupa'da Yunanistan kıyılarından elde edilen örneklerde en fazla $7 \mathrm{~cm}$ kadar bireyler bildirilmiştir (Tablo 2).

Türe ait boy-ağılık ilişkisi parametrelerinden "a" değeri 0,0135; eğim "b" değeri 3,004; korelasyon katsayısı "R2" 0,986 olarak hesaplanmıştır. Hem Türkiye iç suları hem de Yunanistan kıyılarında yapıımış çalışmalarda da söz konusu parametre değerleri birbirine yakın değerler göstermektedir (Tablo 2).

Çalışma sonucunda her ne kadar havzalar arasında büyüme tipi farklılıkları gözlenmiş olsa da tüm bireyler dikkate alındığında $S$. fluviatilis türünün Türkiye içsularında izometrik büyüme gösterdiği anlaşılmıştır. Benzer durum İznik Gölü populasyonu için de geçerli iken, Yunanistan'da yapılmış olan çalışmalarda büyüme tipi ile ilgili bir bilgi yer almamaktadır (Tablo 2).

Aynı türe ait populasyonlarında gözlenen bu farklı büyüme modellerinin, birey sayıları, bölge veya mevsim, habitat, midenin dolu veya boş olması, gonadların olgunluğu, eşey, balığın kondisyonu ve yakalanan balıkların boy gruplarındaki farklılıklardan kaynaklandığı bildirilmiştir (Tesch, 1971).

Tablo 1. S. fluviatilis türünün farklı havzalardaki populasyonlarına ait boy-ağırlık ilişkisi parametreler

Table 1. The length-weight relationship parameters of Salaria fluviatilis in different basins

\begin{tabular}{|c|c|c|c|c|c|c|c|c|}
\hline Havza & $\mathrm{N}$ & $\begin{array}{l}\text { Total boy } \\
\text { Min-Mak } \\
\text { (Ort } \pm G L)\end{array}$ & $\begin{array}{c}\text { Total ağırlık } \\
\text { Min-Mak } \\
\text { (OrtıGL) }\end{array}$ & a & $b$ & $\mathrm{SH}(b)$ & $\mathrm{R}^{2}$ & t-test \\
\hline Marmara & 16 & $\begin{array}{c}2.0-6.0 \\
(4.07 \pm 0.470)\end{array}$ & $\begin{array}{c}0.10-3.57 \\
(1.10 \pm 0.403)\end{array}$ & 0.0104 & 3.206 & 0.1184 & 0.981 & $1.740^{\prime}$ \\
\hline K.Menderes & 69 & $\begin{array}{c}3.0-11.0 \\
(5.44 \pm 0.393)\end{array}$ & $\begin{array}{c}0.41-16.30 \\
(2.72 \pm 0.676)\end{array}$ & 0.0127 & 3.015 & 0.0505 & 0.982 & 0.2901 \\
\hline B.Akdeniz & 175 & $\begin{array}{c}3.5-12.9 \\
(6.21 \pm 0.246)\end{array}$ & $\begin{array}{c}0.56-33.82 \\
(4.13 \pm 0.668)\end{array}$ & 0.0108 & 3.125 & 0.0346 & 0.979 & $3.601^{\mathrm{A}+}$ \\
\hline Antalya & 332 & $\begin{array}{c}2.3-12.0 \\
(5.24 \pm 0.206)\end{array}$ & $\begin{array}{c}0.23-23.83 \\
(2.87 \pm 0.408)\end{array}$ & 0.0140 & 2.990 & 0.0171 & 0.989 & $-0.610^{\prime}$ \\
\hline D.Akdeniz & 39 & $\begin{array}{c}4.7-9.5 \\
(6.51 \pm 0.302)\end{array}$ & $\begin{array}{c}1.48-11.34 \\
(3.83 \pm 0.601)\end{array}$ & 0.0205 & 2.759 & 0.1337 & 0.920 & $-1.806^{\mathrm{A}-}$ \\
\hline Seyhan & 3 & $\begin{array}{c}6.1-7.3 \\
(6.63 \pm 1.239)\end{array}$ & $\begin{array}{c}2.87-4.79 \\
(3.61 \pm 2.098)\end{array}$ & 0.0136 & 2.942 & 0.5307 & 0.969 & $-0.109 \mid$ \\
\hline Ceyhan & 18 & $\begin{array}{c}4.5-8.3 \\
(6.43 \pm 0.478)\end{array}$ & $\begin{array}{c}1.30-7.94 \\
(4.01 \pm 0.938)\end{array}$ & 0.0138 & 2.998 & 0.2590 & 0.893 & -0.007 I \\
\hline Tümü & 652 & $\begin{array}{c}2.0-12.9 \\
(5.61 \pm 0.138)\end{array}$ & $\begin{array}{c}0.10-33.82 \\
(3.24 \pm 0.289)\end{array}$ & 0.0135 & 3.004 & 0.0141 & 0.986 & $0.275^{\prime}$ \\
\hline
\end{tabular}

$\mathrm{N}$ : Birey sayıII, Total boy (cm), GL, Güvenirlik limiti, a ve b büyüme parametreleri, SH (b): eğimin standart hatası, R2: Korelasyon katsayısı, t-test, I: İzometrik, A+: Pozitif allometrik, A-: Negetif allometrik

Tablo 2. Farkıı lokalitelerde yapıımış çalışmalarda S. fluviatilis türüne ait boy-ağırlık ilişkisi parametreleri

Table 2. The length-weight relationship parameters of Salaria fluviatilis in different localities

\begin{tabular}{lcccccccc}
\hline \multicolumn{1}{c}{ Lokalite } & $\mathbf{N}$ & Total boy $(\mathbf{c m})$ & $\mathbf{a}$ & $\mathbf{b}$ & $\mathbf{s e}(\mathbf{b})$ & $\mathbf{R}^{\mathbf{2}}$ & Büyüme tipi & \multicolumn{1}{c}{ Kaynak } \\
\hline Yunanistan & 441 & $2.0-7.0$ & 0.0102 & 3.08 & -- & 0.970 & --- & Kleanthidis vd. 1999 \\
\hline Yunanistan & 409 & $2.0-7.0$ & 0.0068 & 3.33 & --- & 0.990 & --- & Kleanthidis vd. 1999 \\
\hline Yunanistan & 5 & $2.4-6.5$ & 0.0122 & 2.986 & --- & 0.993 & --- & Koutrakis ve Tsikliras 2003 \\
\hline İznik Gölü & 92 & $2.3-4.8$ & 0.0096 & 3.060 & 0.0959 & 0.933 & I & Tarkan vd. 2006 \\
\hline $\begin{array}{l}\text { Türkiye } \\
\text { içsuları }\end{array}$ & 652 & $2.0-12.9$ & 0.0135 & 3.004 & 0.0141 & 0.986 & I & Bu Çalışma \\
\hline
\end{tabular}




\section{KAYNAKLAR}

Geldiay, R., Balık, S., 2007. Türkiye Tatısu Balıkları. Ege Üniversitesi Su Ürünleri Fakültesi Yayınları no: 46 Ders Kitabı Dizini no: 16 Bornovaİzmir, $644 \mathrm{~s}$.

Kleanthidis, P. K., Sinis, A. I., Stergiou, K. I., 1999. Length-weight relationships of freshwater fishes in Greece. Naga, ICLARM Q., 22 (4): $37-41$.

Koutrakis, E. T., Tsikliras, A. C., 2003. Length-weight relationships of fishes from three northern Aegean estuarine systems (Greece). Journal of Applied Ichthyology, 19:258-260. doi: 10.1046/j.1439-0426.2003.00456.x

Krupp, F., Schneider, W., 1989. The fishes of the Jordan River drainage basin and Azraq Oasis. p. 347-416. In Fauna of Saudi Arabia. vol. 10.
Ricker W. E., 1975. Computation and interpretation of biological statistics of fish populations. Bulletin of the Fisheries Research Board of Canada 191: 1-382.

Sokal, R. R., Rohlf, F. J., 1987. Introduction to Biostatistics, 2 nd Edition. Freeman, New York, 363 pp.

Tarkan, A. S., Gaygusuz, Ö., Acıpınar, H., Gürsoy, Ç., Özuluğ, M., 2006. Length-weight relationship of fishes from the Marmara region (NWTurkey). Journal of Applied Ichthyology 22: 271-273. doi: 10.1111/j.1439-0426.2006.00711.x

Tesch, F. W., 1971: Age and growth. In: Methods for assessment of fish production in fresh waters. W. E. Ricker (Ed.). Blackwell Scientific Publications, Oxford, pp. 99-130. 